\title{
Estrogen Dependence of a Gonadotropin-induced Steroidogenic Lesion in Rat Testicular Leydig Cells
}

\author{
S. B. Cigorraga, S. Sorrell, J. Bator, K. J. Catt, and M. L. Dufau, Sections on \\ Molecular Endocrinology and Hormonal Regulation, Endocrinology and \\ Reproduction Research Branch, National Institute of Child Health and Human \\ Development, National Institutes of Health, Bethesda, Maryland 20205
}

A B S T R A C T Leydig cells isolated from the testes of rats treated with intravenous exogenous gonadotropin (hCG) or subcutaneous gonadotropin-releasing hormone $(\mathrm{GnRH})$ show markedly decreased luteinizing hormone $(\mathrm{LH})$ receptors and a partial block in testicular 17,20 desmolase activity. In contrast, Leydig cells from animals with equivalent degrees of $\mathrm{LH}$ receptor loss induced by subcutaneous hCG treatment show no change in 17,20 desmolase activity. These findings indicated that the acuteness of gonadotrophic stimulation, rather than the extent of $\mathrm{LH}$ receptor loss, was responsible for the steroidogenic lesion. A role of estradiol in the enzymatic block produced in vivo by acute elevation of circulating gonadotropin (intravenous hCG or $\mathrm{GnRH}$-stimulated endogenous $\mathrm{LH}$ ) was suggested by rapid elevations of testicular $17 \beta$ estradiol within $30 \mathrm{~min}$ after intravenous hCG, whereas more gradual increases in estradiol occurred 4-8 h after subcutaneous hCG. The inhibitory effect of endogenous estrogen on testicular steroidogenesis was confirmed by the ability of an estrogen antagonist (Tamoxifen) to prevent the reduction of testosterone responses caused by intravenous hCG and subcutaneous GnRH. In addition, Tamoxifen significantly increased the number of $\mathrm{LH}$ receptors in Leydig cells from both control and gonadotropin-desensitized animals. These findings indicate that the acute elevations of intratesticular estrogen produced by treatment with hCG or GnRH are responsible for the steroidogenic lesion seen in gonadotropin-desensitized Leydig cells. These results also suggest that locally produced estrogens contribute to the regulation of testicular LH receptors and 17,20 desmolase activity.

\footnotetext{
Address reprint requests to Dr. Dufau.

Dr. Cigorraga's present address is the Institute for Endocrine Investigation, Children's Hospital, Buenos Aires, Argentina.

Received for publication 1 August 1979 and in revised form 16 November 1.97 .9$.
}

\section{INTRODUCTION}

Previous studies on the gonadotropin-desensitized testis have demonstrated that a partial defect in testicular 17,20 desmolase activity is responsible for the impaired testosterone responses of Leydig cells from rats given intravenous doses of exogenous gonadotropin (hCG), ${ }^{1}$ which causes substantial loss of luteinizing hormone (LH) receptors (1). Acute elevations of endogenous LH, by single subcutaneous doses of gonadotropin-releasing hormone $(\mathrm{GnRH})$, caused a similar steroidogenic lesion with accumulation of $17 \alpha$-hydroxyprogesterone during stimulation of the desensitized Leydig cells in vitro $(2,3)$. The occurrence of simultaneous increases in progesterone production suggested the presence of an additional lesion at the level of $17 \alpha$-hydroxylase. In addition to the negative effects observed after desensitization (i.e., receptor depletion and reduced testosterone responses), there is also increased formation of pregnenolone (1-4). Therefore, the increased progesterone formation in desensitized Leydig cells could result from enhanced precursor production in the presence of the partial enzymatic defects in $17 \alpha$-hydroxylase and 17,20 desmolase activity (2).

In contrast, subcutaneous treatment with hCG that produced similar degrees of $\mathrm{LH}$ receptor loss usually caused no reduction in maximal testosterone responses during hormonal stimulation of dispersed Leydig cells in vitro $(1,3,5)$. Instead, such Leydig cells showed a decrease in sensitivity to hCG (i.e., an increase in halfmaximal effective dose), as might be expected of receptor-depleted target cells in the absence of a change in the effector system, in this case the androgen biosynthetic pathway.

The finding that steroidogenic lesions were promi-

${ }^{1}$ Abbreviations used in this paper: $\mathrm{GnRH}$, gonadotropinreleasing hormone; hCG, exogenous gonadotropin; LH, luteinizing hormone. 
nent after rapid elevations of circulating hCG or $\mathrm{LH}$, but not after subcutaneous hCG that caused equivalent receptor depletion, indicated that the biosynthetic lesion was related to effects of $\mathrm{LH}$ in the Leydig cell, instead of receptor regulation per se. The appearance of the steroidogenic lesions before the maximum decrease in $\mathrm{LH}$ receptors, and their recovery before $\mathrm{LH}$ receptors and cyclic AMP responses returned to normal, also indicated that receptor loss was not directly responsible for the transient steroidogenic lesions (1-4).

The steroid biosynthetic changes in rats treated with hCG or GnRH resembled the enzymatic inhibition produced in rodents by administration of estrogens $(6,7)$, which cause suppression of $17 \alpha$-hydroxylase and 17,20 desmolase activities. For this reason, we investigated the role of endogenous estrogen in the biosynthetic lesion observed in gonadotropin-desensitized Leydig cells.

\section{METHODS}

Adult male rats $(200-250 \mathrm{~g})$ were obtained from Charles River Breeding Laboratories Inc., Wilmington, Mass. Gonadotropin-induced desensitization of Leydig cells was achieved by intravenous injection of hCG (Pregnyl, Organon Inc., West Orange, N. J., 3,000 IU/mg via the jugular vein under ether anesthesia at a dose of $10 \mathrm{IU}$ (equivalent to $1 \mu \mathrm{g}$ of purified hCG) in $100 \mu$ l of phosphate-buffered saline $\mathrm{pH} 7.4$ or by subcutaneous injection of $10 \mu \mathrm{g} \mathrm{GnRH}$ (Beckman Bioproducts, Silver Spring, Md.) in phosphate-buffered saline $\mathrm{pH}$ 7.4. The anti-estrogen Tamoxifen [trans 1 - $(p-\beta$-dimethylamino etoxyphenyl-1,2 diphenylbut-1 ene; I.C.I. Organics, Inc., Stanford, Conn. 46,474] was administered with the intravenous hCG dose or alone at a dose of $1.5 \mu \mathrm{g}$ in controls and before subcutaneous administration of $\mathrm{LH}$ releasing-hormone. An additional intramuscular injection of $100 \mu \mathrm{l}$ phosphate-buffered saline $\mathrm{pH} 7.4$ containing $1.5 \mu \mathrm{g}$ Tamoxifen was administered immediately after the above treatment. Animals were killed by decapitation 2 or $3 \mathrm{~d}$ after injection of gonadotropin or GnRH, and interstitial cells from testes of normal and treated animals were prepared by collagenase digestion as previously described (8). The cells were further fractionated by density gradient centrifugation in Metrizamide (Accurate Chemical, Hicksville, N. Y.), giving purified cell preparations containing over $90 \%$ Leydig cells as judged by morphological criteria and metabolic responses (9). The purified Leydig cells were washed once and resuspended in medium 199 (Microbiological Associates, Bethesda, Md.) containing 0.1\% bovine serum albumin (Armour Pharmaceutical, Kankakee, Ill.). The proportion of incubation medium to cells was equivalent to $2 \mathrm{ml} /$ testis, giving about $10^{6}$ purified Leydig cells/ml. Cell concentrations were determined by counting at least 500 cells in a LEVY ultraplane counting chamber (Arthur Thomas, Philadelphia, Pa.) after histochemical staining for $\Delta_{5}$ $3 \beta$-hydroxysteroid dehydrogenase as previously described (10). Leydig cells were incubated with purified hCG $(10,000 \mathrm{IU} / \mathrm{mg}$; provided by Dr. R. E. Canfield, Columbia University, New York.) or dibutyryl cyclic (c)AMP $\left(\mathrm{Bt}_{2} \mathrm{cAMP}\right.$; Sigma Chemical Co., St. Louis, Mo.). When pregnenolone accumulation was to be measured, inhibitors of $3 \beta$-hydroxysteroid dehydrogenase (1 $\mu \mathrm{M}$ cyanoketone, Upjohn Co., Chicago, Ill.) and 17-hydroxylase ( $10 \mu \mathrm{M}$ spironolactone, G. D. Searle and Co., Chicago, Ill.) were added to cell incubations $20 \mathrm{~min}$ before the addition of stimuli; control incubations were treated similarly (1).

In other experiments, groups of rats were studied after the following treatments $(a)$ control; $(b)$ intravenous injection of $1 \mu \mathrm{g} \mathrm{hCG}$; (c) intravenous injection of $1 \mu \mathrm{g} \mathrm{hCG}$ plus $1.5 \mu \mathrm{g}$ Tamoxifen i.v. and $1.5 \mu \mathrm{g}$ i.m.; $(d)$ subcutaneous injections of $10 \mu \mathrm{g} \mathrm{hCG}$. The rats were killed at selected times after the injections $(0.5,1,2,4$, and $8 \mathrm{~h})$. Blood samples collected from the decapitated animals were allowed to clot, and serum was stored at $-70^{\circ} \mathrm{C}$ before testosterone analysis. Testes were removed and kept frozen at $-70^{\circ} \mathrm{C}$ until analyzed for estradiol$17 \beta$, testosterone, progesterone, and $17 \alpha$-hydroxyprogesterone.

Assays of steroids and serum hCG. Decapsulated testes were homogenized in $2 \mathrm{ml}$ of PBS/testis and extracted with ethyl acetate after addition of tracer amounts of ${ }^{3} \mathrm{H}$-steroids to account for losses during the fractionation procedure. As previously described (11), testosterone was measured by direct radioimmunoassay in the incubation media diluted 1:10 or 1:25 with PBS. The testosterone content of testis extracts and serum was determined after isolation of the steroid by thin-layer chromatography (12). Pregnenolone was measured by the method of di Pietro et al. (13) with a highly specific rabbit antiserum to the 11-hemisuccinate albumin conjugate. Radioimmunoassay of $17 \alpha$-hydroxyprogesterone was performed with an antiserum to the 3-carboxymethyloxime derivative. Because the antiserum to $17 \alpha$-hydroxyprogesterone showed significant cross-reactivity with progesterone (14\%), the two steroids were separated by thin-layer chromatography before assay, when progesterone was present in testis extracts. $17 \beta$-estradiol assays were performed as described by Wung and Lundey (14) using a highly specific rabbit antiserum to 6-ketoestradiol conjugated to bovine serum albumin (Steraloids, Wilton, N. H.). Only minor cross-reaction was observed with the following phenolic steroids: estrone $0.83 \%$; estriol $0.67 \%$; 16-ketoestradiol $1.8 \%$; 16-epiestriol $3.8 \%$; estradiol-3-glucuronide $0.69 \%$; estradiol-17-glucuronide $0.091 \%$. No cross-reaction was observed with any other steroid tested, including testosterone, androstenedione, progesterone, pregnenolone, $17 \alpha$-hydroxypregnenolone, $17 \alpha$ hydroxyprogesterone, estradiol 3,17 disulfate, and estradiol3-glucuronide. All steroids that showed minor cross-reaction were well resolved during the chromatographic separation used in this study. Almost identical values were obtained when extracts were purified by LH-Sephadex (Pharmacia Fine Chemicals Inc., Piscataway, N. J.) column chromatography before assay. Immunoreactive serum hCG concentrations were measured by a specific assay procedure employing anti-hCG $\beta$ as the first antibody (15).

Assay of LH receptors in dispersed Leydig cells. Radioiodinated hCG tracer was prepared by lactoperoxidase method and purified by Sepharose-concanaval in A chromatography (Pharmacia Fine Chemicals Inc.) as previously described (16). Purified Leydig cells $\left(5 \times 10^{5}\right)$ were incubated for $3 \mathrm{~h}$ at $34^{\circ} \mathrm{C}$ with $5 \times 10^{5} \mathrm{dpm}$ of ${ }^{125} \mathrm{I}$-hCG (specific activity $40 \mu \mathrm{Ci} / \mu \mathrm{g}$ ) with addition of $2.5,5$, and $10 \mathrm{ng}$ of $\mathrm{hCG}$ to ensure receptor saturation. The final concentration of hCG in receptor assays employing tracer plus $10 \mathrm{ng}$ hCG was $\sim 0.25 \mathrm{nM}$, or $\sim 10$ times the $K_{d}$ of the binding reaction between hCG and testicular LH receptors. Nonspecific binding was determined by incubation of cells with the labeled hormone in the presence of $10 \mu \mathrm{g}$ unlabeled hCG. All binding capacities were calculated from eight replicate estimations of specific ${ }^{125}$ I-hCG binding at saturation, with corrections for specific activity and maximum bindability of the tracer preparation as previously described (2). The mean binding capacity was calculated for each of the experimental groups and expressed as a percentage of control values, or as the number of receptor sites per cell. 


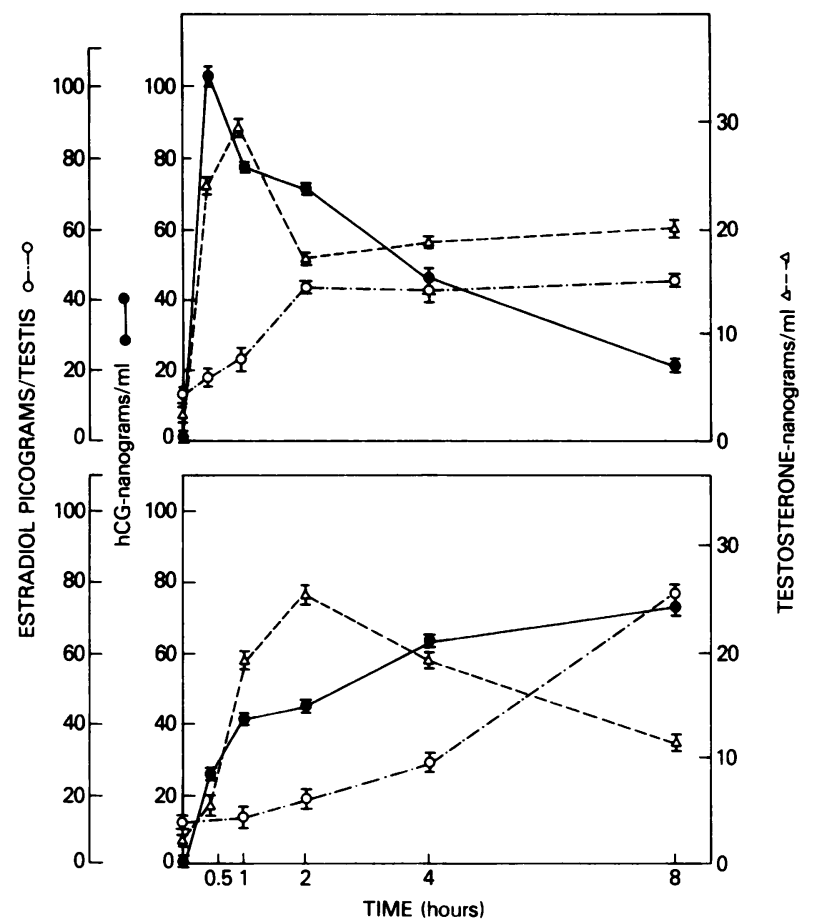

FIGURE 1 Testicular content of testosterone and estradiol$17 \beta$, and serum hCG levels, at times from 0 to $8 \mathrm{~h}$ after treatment with intravenous and subcutaneous hCG. Aboveeffects of $1 \mu \mathrm{g}$ hCG i.v., which caused subsequent impairment of testosterone responses of Leydig cells in vitro. Beloweffects of $10 \mu \mathrm{g}$ hCG s.c., which produced receptor downregulation without loss of maximum testosterone responses in vitro. Data are the mean $\pm S E$ of values derived from six animals. $\triangle$, Testosterone $\mathrm{ng} / \mathrm{ml} ; 0, \mathrm{hCG} \mathrm{ng/ml;} \bigcirc$, estradiol pg/testis.

\section{RESULTS}

In initial studies, testicular estrogen, serum testosterone, and serum hCG concentrations were measured after intravenous and subcutaneous treatment with hCG (Fig. 1). After intravenous hCG, testicular estrogen levels were increased at $30 \mathrm{~min}$, reached maximal levels at $2 \mathrm{~h}$, and then remained elevated for up to $8 \mathrm{~h}$. In contrast, subcutaneous hCG caused a more gradual increase in estrogen levels between 4 and $8 \mathrm{~h}$. Serum testosterone levels reached maximum levels $1 \mathrm{~h}$ after intravenous hCG, preceding the maximal increases of testicular estrogen, and then decreased to $50 \%$ of peak levels at $2 \mathrm{~h}$ when the estrogen response was maximum. Thereafter, both androgen and estradiol-17 $\beta$ levels remained elevated for up to $8 \mathrm{~h}$. In animals treated with subcutaneous hCG, serum testosterone levels increased more slowly, reaching maximal levels at $2 \mathrm{~h}$ and declining gradually between 2 and $8 \mathrm{~h}$. The estrogen content of the testis rose slowly over the first $2 \mathrm{~h}$ and more rapidly between 4 and $8 \mathrm{~h}$ when the serum testosterone level was falling. The increases in serum testosterone paralleled the profile of hCG during the first $2 \mathrm{~h}$ after intravenous and subcutaneous injection, but differed at later times. After intravenous hCG treatment, testosterone values remained constant from 2 to $8 \mathrm{~h}$ although hCG declined gradually to $\approx 20 \%$ of maximal values observed at $0.5 \mathrm{~h}$. After subcutaneous hCG treatment, serum hCG and testosterone rose together during the first $2 \mathrm{~h}$, then serum testosterone declined by about $50 \%$ after $8 \mathrm{~h}$, whereas the serum hCG level rose significantly over this period.

The effects of the antiestrogen Tamoxifen on cell responsiveness $3 \mathrm{~d}$ after treatment with a desensitizing dose of $1 \mu \mathrm{g} \mathrm{hCG}$ are shown in Fig. 2. The LH receptor concentration in the three groups (above) were 17,830, 1,120 , and 2,520 sites/cell, respectively, for the control, hCG, and hCG + Tamoxifen groups. Values for the same groups in the experiment shown above were 15,340, 1,490 , and 3,530 sites/cell. In these experiments, cells from animals treated with Tamoxifen alone showed significant increases of 20 and $30 \%(P<0.01)$ in the number of $\mathrm{LH}$ receptors. Testosterone production by Leydig cells was studied under basal conditions and after incubation with maximal stimulating doses of hCG $(1 \mathrm{nM})$ and dibutyryl cAMP $(1 \mathrm{mM})$. Prior treatment with $1 \mu \mathrm{g} \mathrm{hCG}$

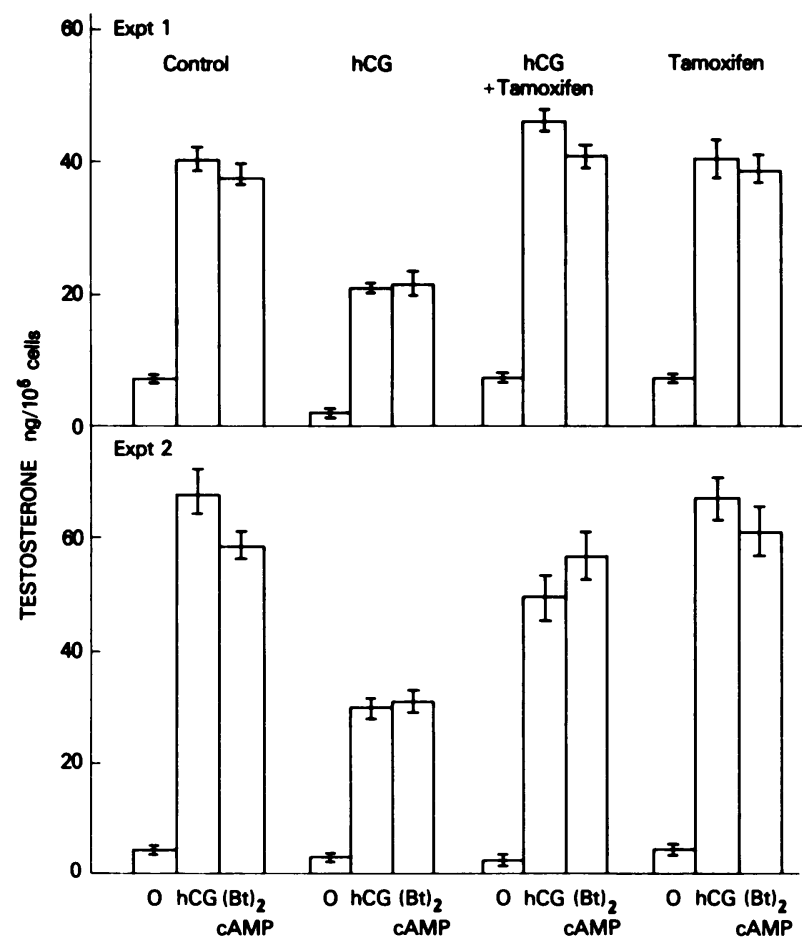

Figure 2 Testosterone production in vitro by Leydig cells prepared from control animals, and from animals treated with a single intravenous dose of $1 \mu \mathrm{g} \mathrm{hCG}$, or $1 \mu \mathrm{g}$ hCG + Tamoxifen (1.5 $\mu \mathrm{g}$ i.v. followed by $1.5 \mu \mathrm{g}$ i.m.), or with Tamoxifen alone. Cells were incubated under basal conditions and in the presence of $1 \mathrm{nM}$ hCG or $1 \mathrm{mM}$ dibutyryl cAMP. Data are the mean $\pm S E$ of results from quadruplicate incubations. 
produced $90 \%$ decline in LH receptors in both experiments, and $50 \%$ reduction of cellular testosterone response to hCG in vitro. However, in these and other experiments, pregnenolone formation, measured in the presence of cyanoketone and spironolactone to inhibit pregnenolone metabolism (1), was maintained or increased when compared with testosterone production in control cells stimulated with hCG in the absence of inhibitors. Pregnenolone values in incubations with hCG were: experiment $1-38 \pm 2.4,46 \pm 3.0,53 \pm 4.5$, and $42 \pm 3.8 \mathrm{ng} / 10^{6}$ cells for the control, i.v. hCG, i.v. hCG + Tamoxifen, and Tamoxifen groups, respectively; experiment $2-73 \pm 8.2,120 \pm 10,128 \pm 11$, and $71 \pm 6.5 \mathrm{ng} / 10^{6}$ cells in the same groups.

Administration of Tamoxifen with the desensitizing dose of hCG had two effects on the Leydig cell. In addition to the slight increase in the number of $\mathrm{LH}$ receptors described above, there was significant recovery of testosterone responses when compared with the control values. Also, Tamoxifen alone did not increase the in vitro testosterone responses to hCG and dibutyryl cAMP (Fig. 2). In 2 of the 10 experiments, significant increases of $30-50 \%(P<0.001)$ in basal and hCG-stimulated testosterone production were observed during incubation of Leydig cells from Tamoxifen-treated control (i.e., nondesensitized) animals, as shown by the experiment illustrated in Fig. 3. This experiment also demonstrates the marked reduction of hCG-stimulated testosterone production by Leydig cells from intravenous hCG-desensitized animals. Tamoxifen administration with hCG prevented this reduction in maximal testosterone response. In this experiment Tamoxifen again increased the number of $\mathrm{LH}$ receptors above the control value (21,190 vs. $17,830 \mathrm{LH}$ sites/cell, $P<0.01)$. Similarly, in hCG-desensitized animals, with reduction of LH receptors to 1,120 sites/cell ( $6.8 \%$ of control), a significant increase in receptor number was produced by treatment with Tamoxifen (to 2,520 sites/cell or $11.8 \%$ of the Tamoxifen-treated control group).

The testicular contents of testosterone, progesterone, and $17 \alpha$-hydroxyprogesterone in these experiments are shown in Table I. The testosterone content of the testis reached near-maximal values from 30 to $60 \mathrm{~min}$ after intravenous hCG injection, similar to the increase observed in plasma testosterone (Fig. 1), and remained elevated for up to $8 \mathrm{~h}$. In contrast, subcutaneous injection of hCG caused a gradual increase in the testosterone content of the testis, reaching maximal levels at $8 \mathrm{~h}$. This change in testicular testosterone paralleled the rise in serum hCG and the testicular estradiol content, but diverged from the serum testosterone concentration, which decreased between 4 and $8 \mathrm{~h}$. The peak in testicular testosterone content was observed at $30 \mathrm{~min}$, coincident with the peak of serum hCG, and was significantly higher in the tamoxifen-

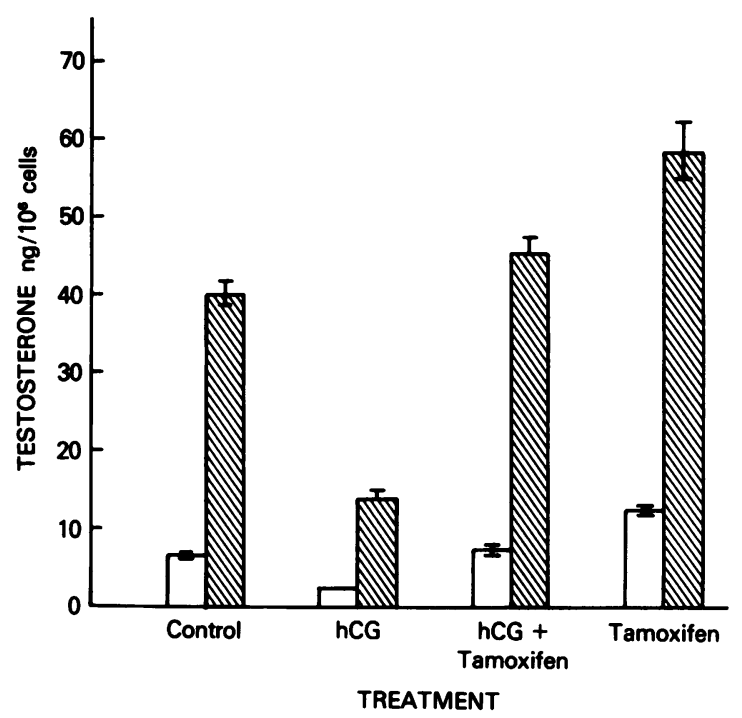

FIGURE 3 Testosterone production in vitro by Leydig cells prepared from control animals and rats treated $3 \mathrm{~d}$ before with a single intravenous dose of hCG $(1 \mu \mathrm{g})$, alone or in combination with $1.5 \mu \mathrm{g}$ of Tamoxifen i.v. followed by $1.5 \mu \mathrm{g}$ Tamoxifen i.m. Another group of animals was treated with Tamoxifen alone. Values are the mean $\pm S E$ of quadruplicate incubations. $\square$, control; $\mathbb{Q}$, hCG.

treated group $(P<0.01)$ at $30 \mathrm{~min}$ and $2 \mathrm{~h}$ after hCG administration. The progesterone and $17 \alpha$-hydroxyprogesterone levels were generally lower in the intravenous hCG/tamoxifen-treated group than in the intravenous hCG group, but these differences were not statistically significant. The ratios of testosterone: progesterone and testosterone: $17 \alpha$-hydroxyprogesterone were significantly higher in the tamoxifen-treated group than in the intravenous hCG group $(P<0.05)$. Tamoxifen was also found to inhibit the steroidogenic lesion in GnRH-desensitized cells (Fig. 4), in which the reduction of maximal testosterone responses to hCG was prevented by simultaneous treatment with the antiestrogen.

\section{DISCUSSION}

The major implications of these results are that acute changes in testicular estrogens are involved in the regulation of 17,20 desmolase activity in the Leydig cell, and that increased estradiol production is responsible for the impairment of androgen production in gonadotropin-desensitized Leydig cells. The inhibitory effect of endogenous estradiol-17 $\beta$ on the activity of the 17,20 desmolase and $17 \alpha$-hydroxylase enzymes, presumably exerted via the estrogen receptors of the Leydig cell (17), is indicated by the ability of Tamoxifen to prevent the characteristic impairment of maximal testosterone production exhibited by desensitized Leydig cells in vitro. 
TABLE I

Testicular Steroid Content after Treatment with hCG Alone or in Combination with Tamoxifen

\begin{tabular}{clccr}
\hline Treatment & Time & Testosterone & Progesterone & $\begin{array}{r}\text { 17 } \alpha \text {-Hydroxy- } \\
\text { progesterone }\end{array}$ \\
\hline Intravenous hCG, $1 \mu \mathrm{g}$ & $h$ & & & \\
& 0 & $21.0 \pm 1.5$ & $14 \pm 2.0(1.5)$ & $17 \pm 0.9(1.2)$ \\
& 0.5 & $286 \pm 20$ & $83 \pm 7.2(3.5)$ & $148 \pm 8.0(1.9)$ \\
& 1 & $305 \pm 18$ & $45 \pm 3.1(6.7)$ & $112 \pm 10(2.7)$ \\
Intravenous hCG, 1 $\mu \mathrm{g}$ & 2 & $220 \pm 10$ & $39 \pm 2.7(5.6)$ & $72 \pm 6.1(3.1)$ \\
+ Tamoxifen & 4 & $423 \pm 29$ & $73 \pm 8.0(5.8)$ & $156 \pm 12(2.7)$ \\
& 8 & $373 \pm 32$ & $68 \pm 5.5(5.5)$ & $141 \pm 11(2.6)$ \\
Subcutaneous hCG, 10 $\mu \mathrm{g}$ & 0.5 & $420 \pm 33$ & $45 \pm 3.2(9.3)$ & $98 \pm 6.0(4.3)$ \\
& 1 & $338 \pm 23$ & $35 \pm 2.9(9.7)$ & $95 \pm 5.2(3.6)$ \\
& 2 & $293 \pm 22$ & $44 \pm 3.5(6.7)$ & $71 \pm 6.5(4.1)$ \\
& 4 & $453 \pm 32$ & $39 \pm 2.9(11.6)$ & $81 \pm 6.9(5.6)$ \\
& 8 & $323 \pm 27$ & $48 \pm 3.0(6.7)$ & $109 \pm 8.2(3.0)$ \\
& 1 & $223 \pm 21$ & $26 \pm 1.8(8.6)$ & $55 \pm 4.5(4.1)$ \\
& 2 & $291 \pm 27$ & $41 \pm 3.0(7.1)$ & $60 \pm 7.0(4.8)$ \\
& 4 & $335 \pm 39$ & $31 \pm 4.5(11.0)$ & $62 \pm 5.0(5.4)$ \\
& 8 & $523 \pm 42$ & $92 \pm 10(5.7)$ & $36 \pm 5.7(5.8)$ \\
\hline
\end{tabular}

Figures in parentheses are ratios of testosterone:progesterone and testosterone: $17 \alpha$-hydroxyprogesterone. Values are the mean $\pm \mathrm{SE}$ of steroids (nanograms/testis) measured in groups of six animals.

The antiestrogen used in this study was administered in minimal effective doses to avoid the changes in $\mathrm{LH}$ secretion that occur after prolonged treatment with

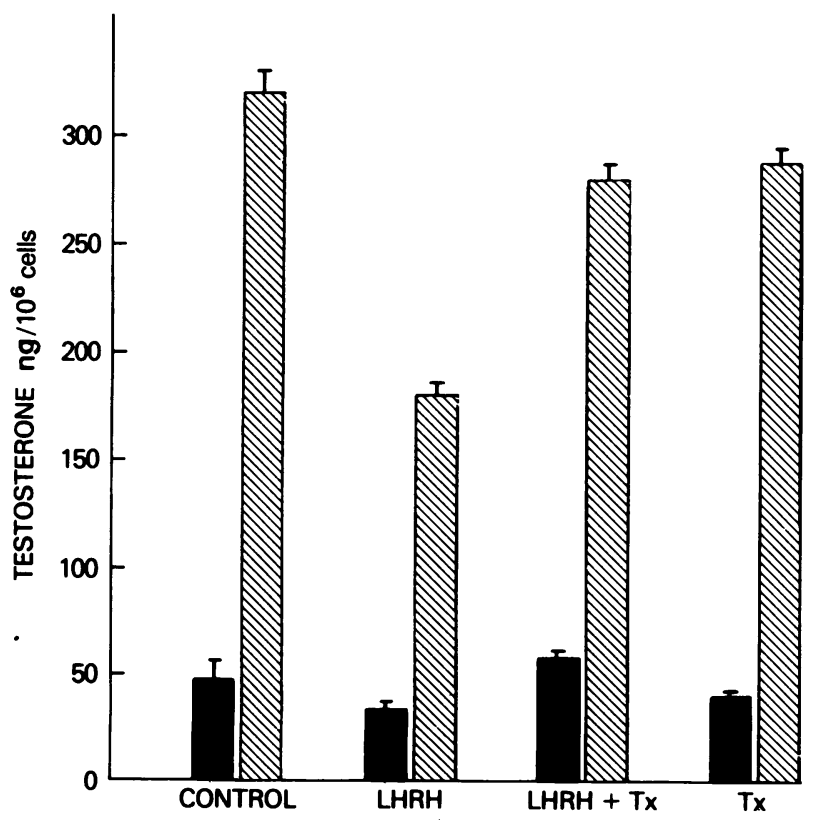

FIGURE 4 Testosterone production by isolated Leydig cells from control animals and rats treated $2 \mathrm{~d}$ before with a single subcutaneous dose of $\mathrm{LH}$ releasing-hormone $(10 \mu \mathrm{g})$. Values are the mean $\pm S D$ of quadruplicate incubations. $\mathbf{a}$, control; \&, hCG $1 \mathrm{nM}$. high doses of Tamoxifen (18) and the direct effects of Tamoxifen on aromatase activity (19). Low doses of Tamoxifen have been shown to produce significant antiuterotropic effects, and single subcutaneous doses of $10 \mu \mathrm{g}$ Tamoxifen depleted cytoplasmic uterine estrogen receptors by $75 \%$ at $3-8 \mathrm{~h}$, followed by low receptor levels for $24 \mathrm{~h}$ and a return to normal at $48 \mathrm{~h}(20)$. In the present study estrogen increases were observed within the $8 \mathrm{~h}$ following acute rises of plasma gonadotropin after intravenous hCG or elevation of endogenous LH by GnRN, at the time when maximal cytoplasmic receptor depletion would presumably occur after Tamoxifen treatment. The estrogen levels returned to control values at $16 \mathrm{~h}$ before the return of estradiol receptors after tamoxifen treatment. ${ }^{2}$

A small but significant increase in LH/hCG receptors was consistently observed in the Tamoxifen-treated animals, both in controls and in gonadotropin-desensitized testes. This finding is relevant to our previous observation that estrogen treatment reduced the concentration of testicular $\mathrm{LH}$ receptors in hypophysectomized animals, and prevented the rise of $\mathrm{LH}$ receptors induced by follicle-stimulating hormone treatment (21). Therefore, it appears likely that the intratesticular concentration of estrogen modulates the number of LH receptors in the Leydig cell. How-

${ }^{2}$ Nozu, K., and M. L. Dufau. 1980. Estradiol receptor translocation and desmolase regulation in gonadotropin-desensitized Leydig cells. Endocrinology. 106A. (Abstr.) 
ever, the retention of Leydig cell responses observed in this study after Tamoxifen treatment was not attributable to the increased number of $\mathrm{LH}$ receptors, because previous experiments $(1,3,4)$ in desensitized cells showed that retention of up to $35 \%$ of the receptors was accompanied by $50-80 \%$ impairment of testosterone production.

The prevention of steroidogenic lesions by Tamoxifen is exerted through the antiestrogenic effect of this compound, by inhibiting the partial block of 17,20 desmolase caused by acute elevation of estrogen after intravenous hCG or elevations of endogenous LH by $\mathrm{GnRH}$ treatment. A direct inhibitory effect of estrogen on testosterone production by Leydig cells has been demonstrated in hypophysectomized rats treated with follicle-stimulating hormone. In such animals, treatment with low doses of estrogen abolished the folliclestimulating hormone-induced testicular changes in a dose-dependent manner (i.e., testosterone responses to hCG, LH receptors, and testicular weight [21]). Also, administration of diethylstilbestrol to men with prostatic cancer resulted in a marked decrease of circulating testosterone levels (to 5\% of control) with only moderate reductions in plasma LH (22). Such findings have indicated the ability of pharmacological amounts of estrogen to exert a direct inhibitory effect on testicular androgen production, and this has been localized in rodents to the 17,20 desmolase step (5). The present observations have shown that physiological changes in estrogen production also influence 17,20 desmolase activity and androgen production, and suggest that endogenous estrogen may have a tonic inhibitory action in the normal control of testicular steroidogenesis.

In man, the present findings may be relevant to the reduced gonadal testosterone production rates observed in Klinefelter's syndrome $(23,24)$. Such patients have low testicular venous and peripheral plasma testosterone levels and high plasma 17 $\alpha$-hydroxyprogesterone levels (25). This steroidogenic pattern suggests the presence of a lesion of the 17,20 desmolase enzyme, as observed in the gonadotropin-desensitized rat testis. Increased conversion of testosterone to estrogen has been shown to occur in the testis (26) and, peripherally (23), in Klinefelter's syndrome, and similar changes are found in elderly men and patients with hepatic cirrhosis $(27,28)$. Thus, testicular estrogen seems to exert a modulatory effect on the 17,20 desmolase step and upon androgen production by the testis, and this may be increased in conditions associated with elevated estrogen production. Normally testosterone production is probably influenced by a tonic inhibitory effect of estrogen produced in the testis, and that reaching the testis from peripheral sites of aromatization. Although this effect may be minor under normal conditions, it becomes more prominent when estrogen production is increased, as in the clinical conditions noted above and in the experimental model of desensitization (1-4). In the latter, marked suppression of 17,20 desmolase enzymatic activity is clearly responsible for the accompanying decrease in testosterone production $(1,3,4)$.

Our current views on the mechanism of desensitization in relation to steroidogenesis are summarized as follows. Treatment with hCG or GnRH (via endogenous $\mathrm{LH}$ ) produces: $\mathrm{LH}$ receptor down-regulation; increased steroidogenic capacity and testosterone production, with increased estrogen formation from androgen; subsequently, estrogen causes a decrease in the enzymatic activity of 17,20 desmolase and probably of $17 \alpha$-hydroxylase, with reduced androgen production and increases in $17 \alpha$-hydroxyprogesterone and progesterone. These biosynthetic lesions are prevented when Tamoxifen is administered with the desensitizing dose of gonadotropin. Although direct actions of $\mathrm{GnRH}$ in the testis have recently been demonstrated (29), the acute changes observed after GnRH treatment in the present work are similar to those caused by hCG and are attributable to the effect of endogenous LH elevations upon testicular estrogen production.

The effects of exogenous and endogenous gonadotropins on the testis are complex, because the initial activation process is followed by decreased LH receptors and steroid biosynthetic lesions. In addition to the estrogen-dependent steroidogenic block described in this report, an earlier biosynthetic lesion has been noted in Leydig cells after treatment with high doses of hCG that caused almost complete depletion of testicular $\mathrm{LH}$ receptors $(1,4)$. The basis of the lesion, which is before pregnenolone biosynthesis, has yet to be determined, but may also depend on hyperstimulation of the Leydig cell rather than the prominent change in $\mathrm{LH}$ receptor content. The elucidation of steroid biosynthetic lesions produced during hormonal stimulation should contribute to the definition of the intracellular control mechanisms that regulate the steroidogenic enzymes of the Leydig cell.

\section{REFERENCES}

1. Cigorraga, S. B., M. L. Dufau, and K. J. Catt. 1978. Regulation of luteinizing hormone receptors and steroidogenesis in gonadotropin-desensitized Leydig cells. J. Biol. Chem. 253: 4297-4304.

2. Dufau, M. L., and K. J. Catt. 1978. Gonadotropin receptors and regulation of steroidogenesis. Vitam. Horm. 36: 461-592.

3. Dufau, M. L., S. Cigorraga, A. J. Baukal, S. Sorrell, J. M. Bator, J. F. Neubaurer, and K. J. Catt. 1979. Androgen biosynthesis in Leydig cells after testicular desensitization. Endocrinology. 105: 1314-1321.

4. Tsuruhara, T., M. L. Dufau, S. B. Cigorraga, and K. J. Catt. 1977. Hormonal regulation of testicular luteinizing hormone receptors. Effects of cyclic AMP and testosterone 
responses in isolated Leydig cells. J. Biol. Chem. 252, 9002-9009.

5. Dufau, M. L., A. J. Hsueh, S. B. Cigorraga, A. J. Baukal, and K. J. Catt. 1978. Inhibition of Leydig cell function through hormonal regulatory mechanisms. Int. J. Andrology. Suppl. 2. Part 1: 193-239.

6. Samuels, L. T., G. J. Short, and R. A. Huseby. 1964. The effect of diethylstilboestrol on testicular $17 \alpha$-hydroxylase and 17,20 desmolase activities in BALB/c mice. Acta Endocrinol. 45: 487-497.

7. Samuels, L. T., T. Uchikawa, M. Zain-ul-Abedin, and R. A. Huseby. 1969. Effect of diethylstilbestrol on enzymes of cryptorchid mouse testis of BALB/c mice. Endocrinology. 85: 96-102.

8. Dufau, M. L., C. Mendelson, and K. J. Catt. 1974. A highly sensitive in vitro bioassay for luteinizing hormone and chorionic gonadotropin: testosterone production by dispersed Leydig cells. J. Clin. Endocrinol. Metab. 39: 610-613.

9. Conn, P. M., T. Tsuruhara, M. L. Dufau, and K. J. Catt. 1977. Isolation of highly purified Leydig cells by density gradient centrifugation. Endocrinology. 101: 639-642.

10. Mendelson, C., M. L. Dufau, and K. J. Catt. 1975. Gonadotropin binding and stimulation of cyclic adenosine $3^{\prime} 5^{\prime}$ monophosphate and testosterone production in isolated Leydig cells. J. Biol. Chem. 250: 8818-8823.

11. Dufau, M. L., K. J. Catt, and T. Tsuruhara. 1972. A sensitive gonadotropin responsive system: radioimmunoassay of testosterone production by the rat testis in vitro. Endocrinology. 90: 1032-1035.

12. Dufau, M. L., K. J. Catt, T. Tsuruhara, and D Ryan. 1971. Radioimmunoassay of plasma testosterone. Clin. Chim. Acta. 37: 109-116.

13. Di Pietro, D. L., R. D. Brown, and C. A. Strott. 1972. A pregnenolone radioimmunoassay utilizing a new fractionation technique for sheep antiserum. J. Clin. Endocrinol. Metab. 35: 729-735.

14. Wung, Ch-H., and L. Lundey. 1971. Radioimmunoassay of plasma estrogens. Steroids. 18: 90-111.

15. Vaitukaitis, J. L., G. D. Braunstein, and G. T. Ross. 1972. An antibody which specifically measures chorionic gonadotropin in presence of luteinizing hormone. Am.J. Obstet. Gynecol. 113: 751-758.

16. Dufau, M. L., E. J. Podesta, and K. J. Catt. 1975. Physical characteristics of the gonadotropin receptor complex formed in vivo and in vitro. Proc. Natl. Acad. Sci. U.S.A. 72: $1272-1275$.

17. Brinkmann, A. O., E. Mulder, G. J. M. Lamers-Stahlhofen, M. J. Mechielsen, and H. J. van der Molen. 1972. An estradiol receptor in rat testis interstitial tissue. FEBS (Fed. Eur. Biochem. Soc.) Lett. 26: 301-305.

18. Bartke, A., M. Mason, S. Dalterio, and F. Bex. 1978. Effects of Tamoxifen on plasma concentrations of testosterone and gonadotropins in the male rat. J. Endocrinol. 79: 239-240.

19. Watson, J., and J. W. H. Howson. 1977. Inhibition by Tamoxifen of the stimulatory action of FSH on oestradiol$17 \beta$ synthesis by rat ovaries in vitro. J. Reprod. Fertil. 49: $375-376$

20. Jordan, V. C., C. J. Dix, L. Rowsby, and G. Prestwich. 1977. Studies on the mechanism of action of the nonsteroidal antioestrogen Tamoxifen (I.C.I. 46,474) in the rat. Mol. Cell. Endocrin. 7: 177-192.

21. Hsueh, A. J. W., M. L. Dufau, and K. J. Catt. 1978. Direct inhibitory effect of estrogen on Leydig cell function of hypophysectomized rats. Endocrinology. 103: 10961102.

22. Dorner, G., F. Stahl, W. Rohde, and D.Schnorr. 1975. An apparently direct inhibitory effect of oestrogen in the human testis. Endokrinologie. 66: 221-224.

23. Dupre, J., R. V. Brooks, and H. Hyde. 1964. Preliminary observations on testosterone in testicular vein blood from abnormal human testis. J. Endocrinol. 29 (Abstr.) Proc. VII-Viii.

24. Wang, C., W. G. Baker, and H. G. Burger. 1975. Hormone studies in Klinefelter's syndrome. Clin. Endocrinol. 4: 399-411.

25. Stewart-Bentley, M., and R. Horton. 1973. Leydig cell function in Klinefelter's syndrome. Metab. Clin. Exp. 22: $875-884$.

26. Sharma, D. C., and J. L. Gabrielove. 1971. Biosynthesis of testosterone and estrogen in vitro by the testicular tissue from patients with Klinefelter's syndrome. Acta Endocrinol. 66: 737-744.

27. McDonald, P. C., J. M. Grodin, and P. K. Siiteri. 1971. Dynamics of androgen and estrogen in control of gonadal steroid secretion D. T. Baird and J. A. Strone, editors. Edinburgh University Press, Edinburgh, Scotland. 158168.

28. Vermeulen, A., M. Musshi, and L. Verdonck. 1972. Testosterone and estradiol production rates and interconversion in normal males and male cirrhotics. Proceedings of the 4th International Congress of Endocrinology, Abstract 305. Washington, D. C.

29. Hsueh, A. J. W., and G. F. Erickson. 1979. Extra-pituitary inhibition of testicular function by luteinizing hormone releasing hormone. Nature. (Lond.). 281: 66-67. 